\title{
Cell fatty acid composition affects free radical formation during lipid peroxidation
}

\author{
JAMES A. NORTH, ARTHUR A. SPECTOR, AND GARRY R. BUETTNER \\ Department of Biochemistry and Electron Spin Resonance Facility, College of Medicine, \\ University of Iowa, Iowa City, Iowa 52242
}

\begin{abstract}
North, James A., Arthur A. Spector, and Garry R. Buettner. Cell fatty acid composition affects free radical formation during lipid peroxidation. Am. J. Physiol. 267 (Cell Physiol. 36): C177-C188, 1994.-Lipid-derived free radicals generated from intact human U937 monocytes exposed to iron-induced oxidative stress were detected by electron paramagnetic resonance (EPR) with the spin trap $\alpha$-(4-pyridyl-1oxide)- $N$-tert-butylnitrone (POBN). Lipid radical formation was enhanced when the cells were enriched with $n-3$ or $n-6$ polyunsaturated fatty acids. Computer simulation indicated that at least two POBN spin adducts were formed, having spectral characteristics consistent with carbon-centered radicals $\left(a^{\mathrm{N}}=15.9 \mathrm{G}\right.$ and $a^{\mathrm{H}}=2.6 \mathrm{G} ; a^{\mathrm{N}}=15.1 \mathrm{G}$ and $\left.a^{\mathrm{H}}=2.8 \mathrm{G}\right)$. These alkyl radicals are probably formed by $\beta$-scission of alkoxyl radicals. POBN spin adduct formation correlated with ethane generation. Addition of ascorbate to the assay medium greatly increased the radical signal intensity. Although radical generation was cell dependent and POBN spin adducts were observed in cell homogenates, the adducts formed by the intact cells were detected only in the extracellular medium. These findings indicate that the extent of lipid radical formation in response to oxidative stress can be influenced by changes in the polyunsaturated fatty acid composition of the cell lipids and suggest the possibility that carbon-centered lipid radicals may interact with extracellular structures.
\end{abstract}

electron paramagnetic resonance; spin trapping; polyunsaturated fatty acids; oxidant stress

FREE RADICALS are generated in a number of metabolic reactions, and lipids containing polyunsaturated fatty acids in cell membranes and lipoproteins are targets of free radical-mediated oxidation (17). This process of lipid peroxidation consists of three components: initiation in which free radicals are formed, propagation of the radical chain reactions, and termination $(6,25,28)$. Iron or other catalytic metals usually are required to initiate lipid peroxidation (25), and the free radicals generated, such as a lipid-derived carbon-centered radical (L•), lipid peroxyl radical (LOO•), and lipid alkoxyl radical $(\mathrm{LO} \cdot)$, propagate the chain reactions $(28)$. Termination of lipid peroxidation results when the free radicals in the chain propagation step react with other free radicals or antioxidants to form nonradical short-chain hydrocarbon compounds.

We recently reported the electron paramagnetic resonance (EPR) detection of lipid-derived carbon-centered free radical $\alpha$-(4-pyridyl-1-oxide)- $N$-tert-butylnitrone (POBN) spin adducts from a suspension of intact human U937 monocytic leukemia cells exposed to oxidant stress (26). This process was initiated by exposure of the U937 cells to ferrous ions; free radicals were detected by EPR spin trapping. The cell suspensions that generated easily detectable amounts of spin adducts were supple- mented with substantial quantities of docosahexaenoic acid [22:6(n-3), DHA], a polyunsaturated fatty acid containing six double bonds and five methylene carbons that is highly susceptible to lipid peroxidation.

The purpose of the present study was to characterize the conditions necessary for lipid radical formation in intact U937 cells and determine whether this process requires the presence of large amounts of DHA in the cell lipids. During the course of this work, we found that the spin adduct formed by the U937 cells was present in the extracellular fluid. This finding suggests that some lipid radicals either are formed near the cell surface or can otherwise gain access to the extracellular medium, where they might be in a position to initiate oxidative reactions in adjacent extracellular structures.

\section{METHODS}

Materials. POBN and iminodiacetic acid chelating resin were purchased from Sigma (St. Louis, MO). 3-Carboxy-proxyl was obtained from Aldrich (Milwaukee, WI). Fatty acids purchased from $\mathrm{Nu}$ Chek Prep (Elysian, MN) included DHA [22:6(n-3)], eicosapentaenoic acid [20:5(n-3)], arachidonic acid $[20: 4(n-6)]$, eicosatrienoic acid $[20: 3(n-3)]$, linolenic acid [18: $3(n-6)]$, linoleic acid [18:2(n-6)], and oleic acid [18:1(n-9)]. [1-14 $\mathrm{C}]$ DHA (40-60 mCi/mmol) was purchased from Du PontNew England Nuclear Research (Boston, MA). A $0.25 \mathrm{M}$ POBN aqueous stock solution was prepared immediately before use and kept on ice during the experiment.

Cell culture. The human U937 monocytic leukemia cell line was grown in a humidified atmosphere of $95 \%$ air $-5 \% \mathrm{CO}_{2}$ at $37^{\circ} \mathrm{C}$ in RPMI 1640 medium containing $5 \%$ fetal bovine serum, $15 \mathrm{mM} N$-2-hydroxyethylpiperazine- $N^{\prime \prime}$-2-ethanesulfonic acid, and $2 \mathrm{mM}$ L-glutamine (18). The cells were maintained as an exponentially growing culture by passage every $2-3$ days. Cell lipids were modified by the addition of $20 \mu \mathrm{M}$ fatty acid to the growth medium for 2 days (26). Before the experiment, the cells were washed twice with a phosphate-buffered salt solution (PBS) containing $2.7 \mathrm{mM} \mathrm{KCl}, 1.5 \mathrm{mM} \mathrm{KH}_{2} \mathrm{PO}_{4}, 136.8$ $\mathrm{mM} \mathrm{NaCl}$, and $8.1 \mathrm{mM} \mathrm{Na} \mathrm{HPO}_{4}(\mathrm{pH}$ 7.4) to remove any remaining fatty acid-supplemented growth medium. Cells were then resuspended in the PBS at a concentration of $\sim 4 \times$ $10^{6}$ cells $/ \mathrm{ml}$. PBS was treated with chelating resin to remove adventitious catalytic metals using the batch method (5); the absence of catalytic metals was verified with ascorbate (5). Cell protein content was assayed by a modification of the Lowry method in which sodium dodecyl sulfate was added (23). Cell cultures were tested and found to be negative for mycoplasma.

Fatty acid composition. Fatty acid composition was determined by gas-liquid chromatography (GLC) (16). Briefly, washed cells were extracted with $\mathrm{CHCl}_{3}-\mathrm{CH}_{3} \mathrm{OH}(2: 1$, vol/vol $)$ (21), and the lipids were saponified for $45 \mathrm{~min}$ at $70^{\circ} \mathrm{C}$ in $10 \mathrm{~N}$ KOH-95\% ethanol (0.5:10, vol/vol) (14). A known amount of heptadecanoic acid methyl ester (17:0) was added as an internal standard. The fatty acids then were methylated for 10 min at $95^{\circ} \mathrm{C}$ with $12 \% \mathrm{BF}_{3}(16)$ and separated by GLC using a 
1.8-m column packed with $10 \%$ SP2330 on 100-120 mesh Chromosorb Gaschrome WAW. The resultant peaks were identified by comparing the retention times with those of known fatty acid methyl ester standards, and peak areas were determined by automatic integration. Statistical analysis was done using the $t$ test.

Incubations. Unless noted otherwise, $0.5 \mathrm{ml}$ PBS containing $4 \times 10^{6}$ cells $/ \mathrm{ml}$ was used in all incubations. Immediately before placement in the EPR spectrometer cavity, $10 \mathrm{mM}$ (final concn) $\mathrm{POBN}$ was added to the cell suspension. Ferrous iron $(10 \mu \mathrm{l})$ from a stock solution of $5 \mathrm{mM} \mathrm{FeSO}_{4} \cdot \mathrm{H}_{2} \mathrm{O}$ in $10 \mathrm{ml}$ $\mathrm{H}_{2} \mathrm{O}$, containing $50 \mu \mathrm{l}$ concentrated $\mathrm{H}_{2} \mathrm{SO}_{4}$ to stabilize the iron as $\mathrm{Fe}^{2+}$, was added next. The contents of the tube were gently mixed by vortexing and then transferred to an EPR quartz flat cell. In additional experiments, either $10 \mathrm{mM} N$-tert-butyl- $\alpha$ phenylnitrone (PBN) or 2-methyl-2-nitrosopropane (MNP) was substituted for POBN as the spin trap.

Disruption of cells was done by nitrogen cavitation as described previously (21), except that the disruption buffer consisted of PBS alone. In one experiment, the homogenate was centrifuged at $600 \mathrm{~g}$ to remove nuclei and unbroken cells. The resulting supernatant material was mixed with $10 \mathrm{mM}$ POBN and $100 \mu \mathrm{M} \mathrm{FeSO}_{4}$, and EPR spectra were collected. In another experiment, the $600-g$ supernatant material was centrifuged at $10,000 \mathrm{~g}$ to remove mitochondria, and the microsome fraction was then isolated by sedimentation for $1 \mathrm{~h}$ at $100,000 \mathrm{~g}$. After washing, the fatty acid composition of the isolated microsomes was assayed by $\operatorname{GLC}(14,26)$.

Incorporation and release of $\left[1-{ }^{14} \mathrm{C} / \mathrm{DHA}\right.$. To determine the distribution of newly incorporated DHA in the cell lipids, the U937 cells were incubated with $5 \mu \mathrm{M}\left\lfloor 1-{ }^{14} \mathrm{C}\right] \mathrm{DHA}$, washed, and extracted with $20 \mathrm{ml}$ of the $\mathrm{CHCl}_{3}-\mathrm{CH}_{3} \mathrm{OII}$ mixture. After the $\mathrm{CHCl}_{3}$ phase was isolated, the radioactivity was measured in an aliquot by liquid scintillation spectrometry, and the distribution of the radioactivity among the major lipid classes was determined in the remainder of the $\mathrm{CHCl}_{3}$ extract after separation by thin-layer chromatography (TLC) (16). In another experiment, the cells were similarly labeled with $\left[1-{ }^{14} \mathrm{C}\right] \mathrm{DHA}$, and after washing, the cell suspension was divided into four equal portions. Two of these were incubated in PBS, and the other two in PBS containing $100 \mu \mathrm{M} \mathrm{FeSO}$. After $15 \mathrm{~min}$, the cells were sedimented by centrifugation, and the radioactivity contained in the cell pellet and supernatant solution was measured (16).

EPR measurements. EPR spectra were obtained using a Bruker ESP-300 spectrometer operating at $9.79 \mathrm{GHz}$ with $100-\mathrm{kHz}$ modulation frequency. Each sample, contained in a quartz flat cell, was centered in a $\mathrm{TM}_{110}$ cavity. All EPR measurements were made using air-saturated solutions at room temperature. The EPR spectrometer settings were as follows: microwave power, $40 \mathrm{~mW}$ (7); modulation amplitude, $1.05 \mathrm{G}$; time constant, $1.3 \mathrm{~s}$; scan rate, $60 \mathrm{G} / 335 \mathrm{~s}$; receiver gain, $10^{6}$. Quantitation of spectra was done using 3-carboxyproxyl as the radical standard (13). Accurate determinations of POBN spin adduct concentrations by standard double integration in samples with very low signal-to-background ratio could not always be reliably achieved using the Bruker ESP-300 software package. In these cases peak heights were used; values for the height of the first midfield peak and the trough of the second midfield peak were measured. Those spectra having a high signal-to-background ratio were analyzed by both double integration and measurement of midfield peak ranges. Analysis by either method yielded similar radical concentrations. Computer simulation of EPR spectra was performed utilizing programs available from the National Institute of Environmental Health Sciences (12).
Measurement of ethane production. Lipid peroxidation was measured using the generation of ethane as described elsewhere (8). Briefly, $5 \times 10^{7} \mathrm{U} 937$ cells that had been previously supplemented with either $10 \mu \mathrm{M}$ DHA or $10 \mu \mathrm{M}$ oleic acid were washed and resuspended in $5 \mathrm{ml}$ PBS and placed into 10-ml disposable syringes (Becton Dickinson, Rutherford, NJ). A 5-ml headspace was created by a stream of low-hydrocarbon compressed air (Air Products, Allentown, PA) in the syringe above the sample. Compressed air was allowed to flush the headspace for $5 \mathrm{~min}$, and the syringe was then sealed with a $1-\mathrm{ml}$ syringe plunger septum. Experiments were initiated by injection of $50 \mu \mathrm{FeSO}_{4}$ stock solution $(200 \mu \mathrm{M}$ final concn $)$ or PBS through the plunger septum. The samples were mixed and incubated at $37^{\circ} \mathrm{C}$ for $2 \mathrm{~h}$ before analysis of the headspace. The 5-ml headspace gases were directly injected into a HewlettPackard model 5710A gas chromatograph modified with an external heated sample loop for hydrocarbon detection (8). Ethane quantitation was accomplished by separation of one- to four-carbon hydrocarbons on a $5 \mathrm{~m} \times 3.2 \mathrm{~mm}$ stainless steel column packed with 80-100 mesh Poracil C (Supelco, Bellefonte, PA) run isothermally at $50^{\circ} \mathrm{C}$ with $\mathrm{N}_{2}$ as the carrier gas and flame ionization at $150^{\circ} \mathrm{C}$ to detect and quantify peak areas. C1-C6 n-paraffins (10-20 ppm each in $\mathrm{N}_{2}$; Supelco) were used to generate standard curves for quantitation of ethane peak areas.

\section{RESUL'IS}

EPR spin-trapping studies. The spectral intensity of POBN spin adducts $\left(a^{\mathrm{N}}=15.61 \pm 0.04 \mathrm{G}\right.$ and $a^{\mathrm{H}}=$ $2.64 \pm 0.03 \mathrm{G}$ ), generated after iron-mediated oxidative stress, was determined relative to the amount of supplemental DHA present in the growth medium of the U937 cells (Fig. 1). In these and all other studies in which free radicals were measured, the cells were removed from the medium containing the fatty acid supplement and washed before they were incubated with POBN and ferrous iron. Therefore no lipid supplement was contained in the medium when the EPR measurements were made. The intensity of the carbon-centered radical adduct measured by EPR increased as the concentration of DHA to which the cells had been exposed in the growth medium was raised. With the instrument settings used, this adduct was not discernibly detected when DHA-supplemented cells were incubated with POBN alone (Fig. 1A). It was also not discernible when cells grown either without supplemental fatty acid (Fig. $1 B$ ) or with $2.5 \mu \mathrm{M}$ DHA (Fig. $1 C$ ) were incubated with POBN and ferrous iron. However, the POBN spin adduct was clearly detected when the growth medium was supplemented with $5 \mu \mathrm{M}$ DHA (Fig. 1D), and the signal intensity bccame more pronounced as the supplemental DHA concentration was increased further (Fig. $1, E-H)$. On the basis of work using cell-free incubations with purified polyunsaturated fatty acids and lipoxygenases $(9,20)$, we have assigned the spectra to an alkyl radical adduct of POBN, such as an ethyl, pentyl, or pentenyl radical.

Quantitation of the spectra illustrated in Fig. 1 using a 3-carboxy-proxyl standard shows that the amount of radical generated from U937 cells exposed to oxidative stress increased sharply when the supplemental DHA concentration to which the cells had been exposed in the growth medium was increased above $10 \mu \mathrm{M}$ (Fig. 2). 


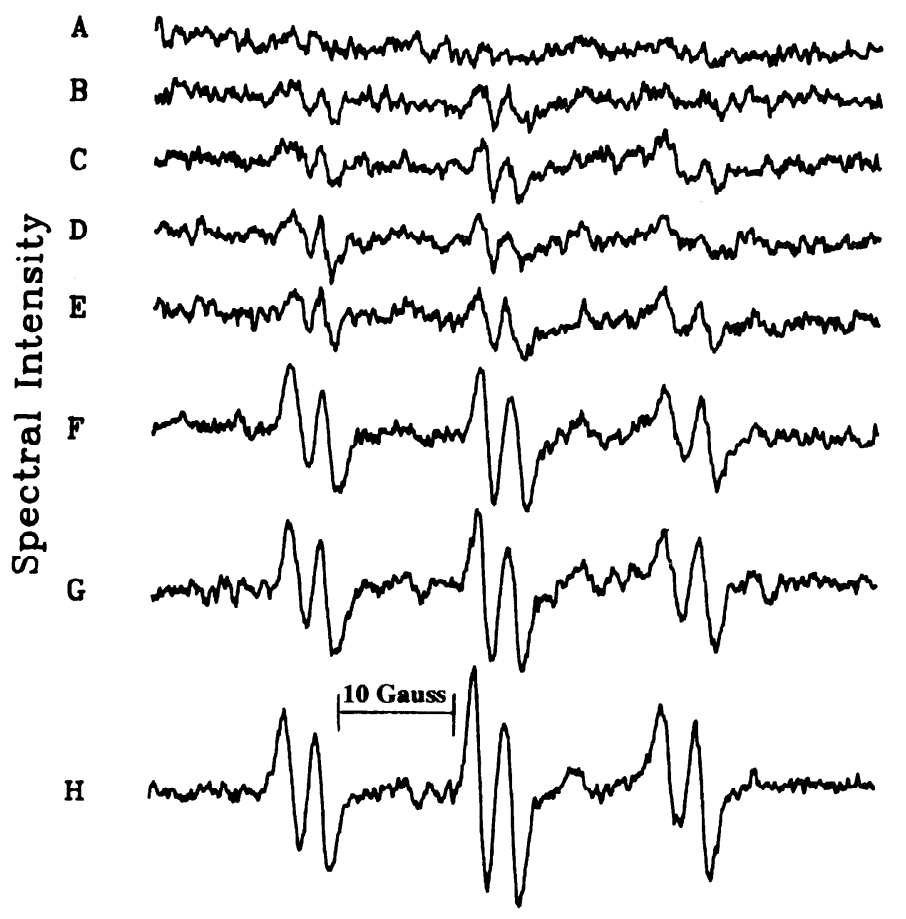

Magnetic Flux Density

Fig. 1. Effect of docosahexaenoic acid (DHA) concentration on $\alpha$-(4pyridyl-1-oxide)- $N$-tert-butylnitrone (POBN) spin adduct signal intensity. U937 cells, grown for 2 days in medium supplemented with varying concentrations of DHA, were washed 3 times with phosphatebuffered saline (PBS) to remove loosely adherent fatty acid. Subsequent incubation was done at room temperature in air-saturated PBS solutions containing $10 \mathrm{mM}$ POBN and $2 \times 10^{6}$ cells in a total volume of $0.5 \mathrm{ml}$. Within $2 \mathrm{~min}$ after addition of $100 \mu \mathrm{M} \mathrm{FeSO}_{4}$, electron paramagnetic resonance (EPR) scans were initiated. $A$ : $20 \mu \mathrm{M}$ DHAsupplemented cells without $\mathrm{FeSO}_{4} ; B$ : cells that did not receive a fatty acid supplement; $C$ : $2.5 \mu \mathrm{M}$ DHA-supplemented cells; $D: 5.0 \mu \mathrm{M}$ DHA-supplemented cells; $E: 10 \mu \mathrm{M}$ DHA-supplemented cells; $F, 20$ $\mu \mathrm{M}$ DHA-supplemented cells; $G, 30 \mu \mathrm{M}$ DHA-supplemented cells; $H$, $40 \mu \mathrm{M}$ DHA-supplemented cells. EPR spectrometer conditions were those listed under METHODS.

Because there is considerable scatter in the data obtained from the cells grown in the presence of $40 \mu \mathrm{M}$ DHA, it appears that radical formation may plateau at supplemental concentrations between 30 and $40 \mu \mathrm{M}$ DHA.

Ethane production. The relationship between POBN radical adduct formation and ethane generation by the U937 cells was compared. When the cells were grown in medium supplemented with $10 \mu \mathrm{M}$ DHA, radicals were trapped and ethane was generated (Table 1). In corresponding cells grown in medium supplemented with oleic acid, lipid-derived radical formation was too low to be detected, and very little ethane was produced.

Enrichment of cell lipids with DHA. The fatty acid composition of cells grown in media supplemented with DHA was determined by GLC. The percentage of total cell fatty acid present as DHA increased as the amount of DHA supplementation was raised, reaching a plateau at $30 \mu \mathrm{M}$ added DHA (Fig. 3). DHA accounted for 2.5\% of the total fatty acid in the fetal bovine serum present in the growth medium, and this probably accounts for the small amount of DHA present in the cells grown in the medium that did not contain any supplemental fatty acid.

The fatty acid composition of the isolated microsomes was also determined after growth of the U937 cells in media supplemented with either $20 \mu \mathrm{M}$ DHA or oleic acid. As a control, microsomes from cells grown in medium without a fatty acid supplement also were isolated and assayed. Compared with the microsomes from the unsupplemented cells, a 10-fold increase occurred in the relative amount of 22:6 in the cells supplemented with DHA, and there was a doubling in the relative content of polyunsaturated fatty acid (Table 2 ). Likewise, there was a $30 \%$ increase in the relative amount of 18:1 in the microsomes from the cells supplemented with oleic acid. 'T'herefore fatty acid compositional changes similar to those observed in the intact cells also occurred in the membranes that comprise the microsomal fraction.

The distribution of the incorporated DHA among the cell lipids was also measured after supplementation. After incubation for $24 \mathrm{~h}$ with $5 \mu \mathrm{M}$ DHA containing $\left[1-{ }^{14} \mathrm{C}\right] \mathrm{DHA}$, the cells were washed and the radioactivity in the extracted lipids was determined after separation by TLC. The radioactivity was distributed primarily among three lipid fractions: $35 \%$ in phosphatidylcholine, $18 \%$ in phosphatidylethanolamine, and $30 \%$ in triglycerides (data not shown).

An experiment was also done to determine whether lipids containing DHA might be discharged from the cells as a result of exposure to $\mathrm{FeSO}_{4}$. After labeling with the $\left[1-{ }^{14} \mathrm{C}\right] \mathrm{DHA}$ and washing, portions of the labeled cell suspension were incubated for 15 min with PBS containing $100 \mu \mathrm{M} \mathrm{FeSO}_{4}$ or PBS alone as a control. In both cases, $5.2-5.4 \%$ of the cell radioactivity was recovered in the medium at the end of the 15-min incubation. Release of a small amount of radioactive lipids during incubation of cells containing labeled DHA has been observed previously (16). The present findings demonstrate that the $\mathrm{FeSO}_{4}$-mediated oxidation did not cause a measurable increase in this release process. Because $\left[1-{ }^{14} \mathrm{C}\right] \mathrm{DHA}$ was used to label the cells, however, this assay is not able to detect the release of oxidation products that do not contain the carboxyl carbon of the added DHA.

Factors affecting radical formation. Trapping of the carbon-centered radical was dependent on the order of addition of compounds into the reaction mixture. When ferrous iron was added before POBN, no lipid-derived radical was detected; the $\mathrm{POBN}$ had to be added before $\mathrm{FeSO}_{4}$ to trap a carbon-centered radical. Adding $1.8 \mathrm{mM}$ final concentration sulfuric acid, which was equal to that used to prepare the $\mathrm{FeSO}_{4}$ stock solution, to DHA-enriched cells in the presence of POBN lowered the $\mathrm{pH}$ of the incubation mixture to 7.0 but did not generate a radical signal.

In most of the experiments, the POBN concentration was $10 \mathrm{mM}$. To ascertain whether this amount was optimal, cells were incubated with various amounts of POBN and after addition of $100 \mu \mathrm{M} \mathrm{FeSO}_{4}$, EPR spectra were obtained. The radical adduct peak heights were determined, and the amount of radical formation was calculated using the 3-carboxy-proxyl standard. Increas- 
Fig. 2. Effect of DHA concentration on quantity of POBN spin adducts generated. Spin adducts formed when $2 \times 10^{6} \mathrm{U} 937$ cells, which had been previously enriched with DHA for $48 \mathrm{~h}$, were incubated with $10 \mathrm{mM}$ POBN and $100 \mu \mathrm{M} \mathrm{FeSO}_{4}$ in a total volume of $0.5 \mathrm{ml}$. Each point represents results obtained from at least 3 separate experiments $\pm \mathrm{SE}$.

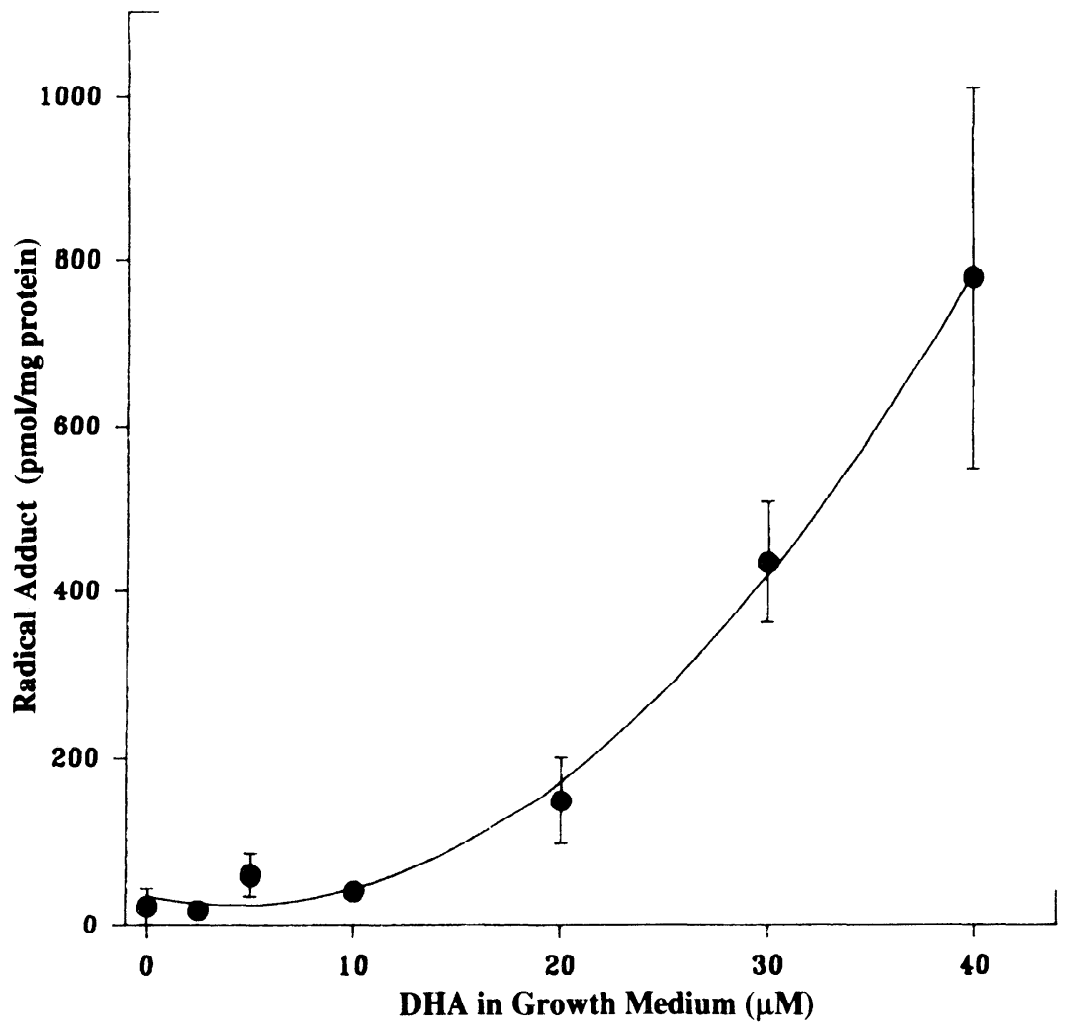

ing the POBN concentration from 0 to $20 \mathrm{mM}$ resulted in larger amounts of radical adduct formation (Fig. 4). At POBN concentrations $<2.5 \mathrm{mM}$, however, the amount of radical adducts formed was equal to or less than the background values at the spectrometer settings used. Although the $80 \mathrm{mM}$ POBN produced a slightly larger amount of trapped radicals than $10-40 \mathrm{mM}$ POBN, breakdown of the spin trap occurred in the presence of $\mathrm{FeSO}_{4}$ when the POBN concentration excceded $40 \mathrm{mM}$. This produced significant artifactual species and interfered with the lipid-radical spectral analysis. Furthermore, trypan blue exclusion studies indicated that POBN concentrations above $40 \mathrm{mM}$ reduced U937 cell viability.

Table 1. Ethane production and radical adduct generation in DHA supplemented U937 cells

\begin{tabular}{|c|c|c|}
\hline \multirow{2}{*}{$\begin{array}{l}\text { Fatty Acid } \\
\text { Supplement }\end{array}$} & \multicolumn{2}{|c|}{$\begin{array}{l}\text { Peroxidation Products, } \\
\mathrm{pmol} /\left(4 \times 10^{6} \text { cells }\right)\end{array}$} \\
\hline & Ethane & Radical adduct \\
\hline $\begin{array}{l}\text { Docosahexaenoic } \\
\text { Oleic }\end{array}$ & $\begin{array}{c}14.9 \pm 1.7 \\
3.7\end{array}$ & $\begin{array}{c}21.3 \pm 4.4 \\
\mathrm{NM}\end{array}$ \\
\hline
\end{tabular}

Cells were grown for 2 days with $10 \mu \mathrm{M}$ supplemental fatty acid, washed three times with phosphate-buffered saline, and resuspended to $10^{7}$ cells $/ \mathrm{ml}$. After exposure to $200 \mu \mathrm{M} \mathrm{FeSO}_{4}$, ethane production was measured from headspace of a $10-\mathrm{ml}$ syringe injected into gas chromatograph. Radical adduct generation was quantitated using $4 \times$ $10^{6}$ cells $/ \mathrm{ml}$ exposed to $\mathrm{FeSO}_{4}$ in the presence of $10 \mathrm{mM} \alpha$-(4-pyridyl-1oxide)- $N$-tert-butylnitrone (POBN). Data for cells enriched with docosahexaenoic acid (DHA) represent mean \pm SE of 3 individual determinations, whereas data for cells enriched with oleic acid are average of 2 determinations. Radical adducts were not measurable (NM) at instrument settings used with cells enriched with oleic acid.

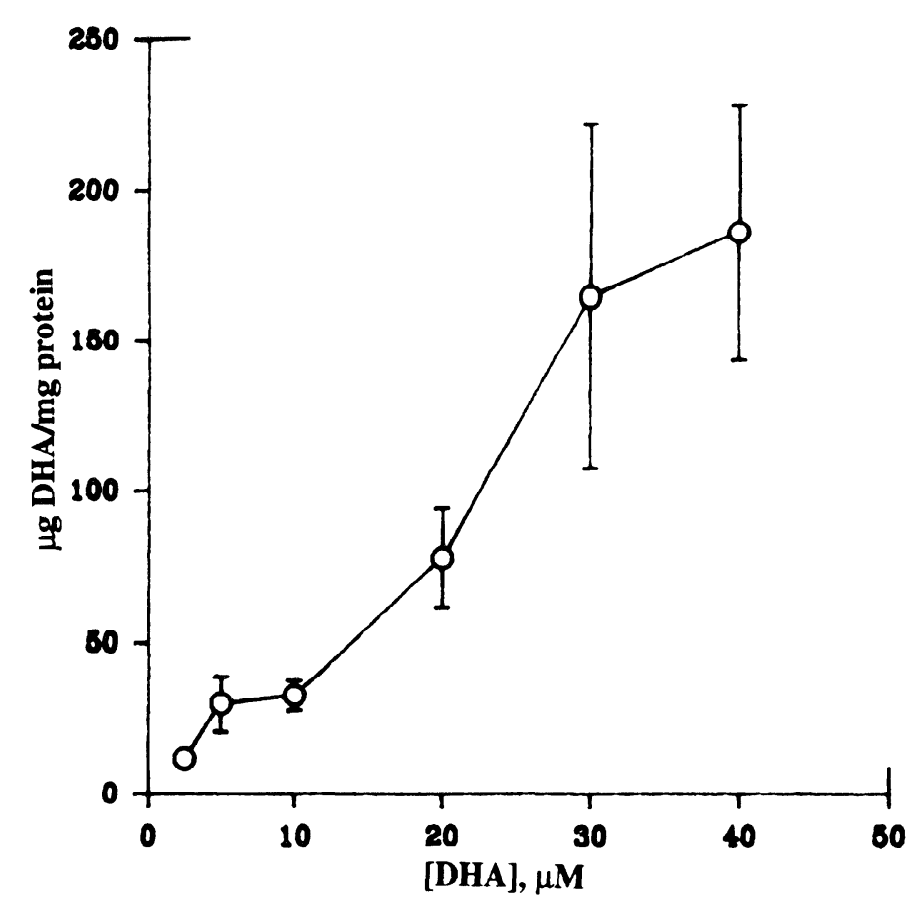

Fig. 3. Correlation between DHA concentration in growth medium and its content in cell lipids. U937 cells were grown for $48 \mathrm{~h}$ in medium supplemented with various concentrations of DHA. Cells were washed 3 times, lipids were extracted with $\mathrm{CH}_{3} \mathrm{Cl}_{-} \mathrm{CH}_{3} \mathrm{OH}(2: 1, \mathrm{vol} / \mathrm{vol})$, and lipid extracts were subjected to alkaline hydrolysis. Fatty acids contained in saponifiable fraction were methylated, and methyl esters were separated by gas-liquid chromatography. Each point represents results obtained from at least 3 separate experiments $\pm \mathrm{SE}$, except for individual samples from 2 different experiments. cells grown in absence of added DHA for which result is average of 2 
Table 2. Growth of U937 cells in presence of fatty acid supplements affects fatty acid composition

of microsomes

\begin{tabular}{lccc}
\hline \hline \multirow{2}{*}{ Fatty Acid } & \multicolumn{3}{c}{ Composition of Microsomes, \% } \\
\cline { 2 - 4 } & $\begin{array}{c}\text { No fatty acid } \\
\text { supplement } \\
(n=5)\end{array}$ & $\begin{array}{c}\text { Oleic acid } \\
\text { supplement } \\
(n=3)\end{array}$ & $\begin{array}{c}\text { DHA } \\
\text { supplement } \\
(n=3)\end{array}$ \\
\hline $14: 0$ & $2.0 \pm 0.4$ & $0.9 \pm 0.1$ & $2.3 \pm 0.6$ \\
$16: 0$ & $15.3 \pm 1.8$ & $13.9 \pm 5.4$ & $17.3 \pm 4.7$ \\
$16: 1$ & $5.2 \pm 0.8$ & $2.8 \pm 0.2$ & $3.3 \pm 0.2$ \\
$18: 0$ & $15.4 \pm 1.5$ & $13.5 \pm 0.9$ & $9.7 \pm 2.2$ \\
$18: 1$ & $23.7 \pm 2.4$ & $31.1 \pm 7.1$ & $11.2 \pm 3.6$ \\
$18: 2$ & $1.3 \pm 0.3$ & $1.1 \pm 0.4$ & $1.1 \pm 0.2$ \\
$18: 3$ & $1.9 \pm 0.1$ & $3.8 \pm 0.7$ & $1.2 \pm 0.1$ \\
$20: 3$ & $1.6 \pm 0.2$ & $1.5 \pm 0.1$ & $1.2 \pm 0.4$ \\
$20: 4$ & $7.6 \pm 0.3$ & $5.0 \pm 0.3$ & $4.5 \pm 0.2$ \\
$20: 5$ & $2.5 \pm 1.0$ & $1.1 \pm 0.8$ & $4.2 \pm 1.3$ \\
$22: 4$ & $2.5 \pm 0.3$ & $2.7 \pm 0.3$ & $1.6 \pm 0.9$ \\
$22: 5$ & $3.4 \pm 0.3$ & $2.5 \pm 0.5$ & $4.0 \pm 2.6$ \\
$22: 6$ & $2.8 \pm 0.7$ & $0.6 \pm 0.6$ & $29.5 \pm 0.9$ \\
Saturated & $34 \pm 1$ & $30 \pm 6$ & $30 \pm 7$ \\
Monosaturated & $30 \pm 3$ & $35 \pm 7$ & $15 \pm 4$ \\
Polyunsaturated & $24 \pm 1$ & $18 \pm 1$ & $47 \pm 5$ \\
Unsaturation index & 1.29 & 1.05 & 2.66 \\
Chain-length index & 15.7 & 14.8 & 17.6 \\
\hline
\end{tabular}

Values are means $\pm \mathrm{SE}$. U937 cells were grown for $48 \mathrm{~h}$ in a medium containing $5 \%$ fetal bovine serum and no fatty acid supplement, $20 \mu \mathrm{M}$ supplemental oleic acid, or $20 \mu \mathrm{M}$ supplemental DHA. After washing and resuspension, cells were homogenized, and a microsomal fraction isolated by sedimentation for $1 \mathrm{~h}$ between 10,000 and 100,000 $\mathrm{g}$. Lipids were extracted with $\mathrm{CHCl}_{3}-\mathrm{CH}_{3} \mathrm{OH}$, and after methylation the fatty acid composition was determined by gas-liquid chromatography (GLC). In each case percentage composition does not total to $100 \%$ because minor and unidentified fatty acids are not included. Unsaturation index is average no. of double bonds, and chain-length index is average no. of carbons in each fatty acid.

In other studies, either $10 \mathrm{mM}$ PBN or $10 \mathrm{mM}$ MNP was used as the spin trap. As opposed to results obtained with POBN in the same experiments, no radical adducts were detected when U937 cells enriched with DHA were exposed to $100 \mu \mathrm{M} \mathrm{FeSO}$ in the presence of either of these spin traps.

Ordinarily, the cells were washed with PBS before the initiation of radical formation. To exclude the possibility that the lipid radical might be formed from unesterified fatty acid that remained loosely bound to the cell surface, cells supplemented with $20 \mu \mathrm{M}$ DHA were washed with PBS containing $10 \mathrm{mM}$ bovine serum albumin before exposure to $\mathrm{POBN}$ and $\mathrm{FeSO}_{1}$. The radical adduct signal detected was the same height and shape as that obtained from corresponding DHAenriched cells washed only with PBS (data not shown).

Cell viability was assessed by trypan blue dye exclusion after exposure to $\mathrm{PBS}$ containing $\mathrm{FeSO}_{4}, \mathrm{POBN}$, $\mathrm{FeSO}_{4}$ plus $\mathrm{POBN}$, or, as a control, $\mathrm{PBS}$ containing none of these additives. After these samples were placed in the EPR spectrometer and the spectral data were collected, the number of cells not stained by the dye was measured by microscopy. In each case, $>94 \%$ of the cells excluded the trypan blue, and no significant differences were observed between any of the treatments (data not shown).

Effect of type of fatty acid supplement. To determine whether polyunsaturated fatty acids other than DHA would also enhance the production of lipid radicals, the U937 cell growth media were supplemented with different fatty acids. Table 3 shows the fatty acid compositional differences that occurred in the total lipids extracted from the cells when the growth medium contained $20 \mu \mathrm{M}$ of one of the following fatty acids: oleic acid [18:1(n-9)], linoleic acid [18:2(n-6)], linolenic acid [18:3(n-6)], eicosatrienoic acid [20:3(n-3)], arachidonic acid [20:4(n-6)], eicosapentaenoic acid [20:5(n-3)], or DHA [22:6(n-3)]. In each case supplementation with a fatty acid led to an increased proportion of that particular fatty acid in the cell lipids, but the degree of increase varied for individual fatty acids. Similar percentage

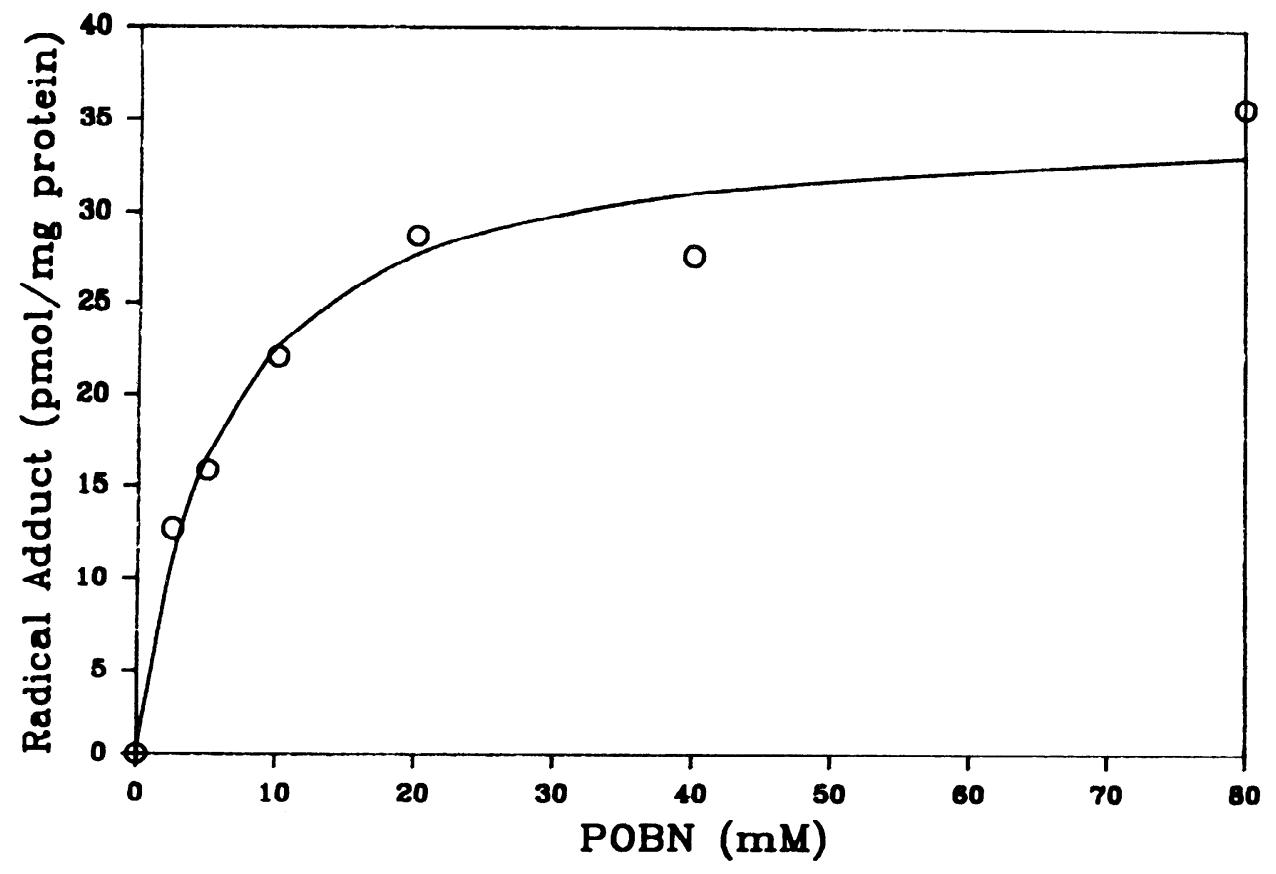

Fig. 4. Effect of POBN concentration on amount of radical adduct generated. U937 cells were grown in medium supplemented with $10 \mathrm{mM}$ DHA for 48 $\mathrm{h}$ and then washed 3 times with PBS. Incubations contained $2 \times 10^{6}$ cells in a total volume of $0.5 \mathrm{ml}$. When no POBN was added, a signal-to-background level representing lower limit of detection at instrument settings used corresponded to a radical adduct amount of 9.8 $\mathrm{pmol} / \mathrm{mg}$ protein. However, in absence of POBN, amount of radical adduct trapped is 0 . Therefore, line reflects curve fitting of radical adduct amounts detectable above $9.8 \mathrm{pmol} / \mathrm{mg}$ and a line constrained to pass through origin. Similar results were obtained in 2 separate experiments; only 1 set of values is presented. 
Table 3. Fatty acid composition in U937 cells grown in fatty acid supplemental media

\begin{tabular}{|c|c|c|c|c|c|c|c|}
\hline \multirow{2}{*}{ Fatty Acid } & \multicolumn{7}{|c|}{ Fatty Acid Composition, \% } \\
\hline & $\begin{array}{c}18: 1(\mathrm{n}-9) \\
\text { supplement }\end{array}$ & $\begin{array}{c}18: 2(n-6) \\
\text { supplement }\end{array}$ & $\begin{array}{c}18: 3(\mathrm{n} 6) \\
\text { supplement }\end{array}$ & $\begin{array}{c}20: 3(\mathrm{n}-3) \\
\text { supplement }\end{array}$ & $\begin{array}{c}20: 4(\mathrm{n}-6) \\
\text { supplement }\end{array}$ & $\begin{array}{c}20: 5(\mathrm{n}-3) \\
\text { supplement }\end{array}$ & $\begin{array}{c}22: 6(\mathrm{n}-3) \\
\text { supplement }\end{array}$ \\
\hline $16: 0$ & $8.6 \pm 0.7$ & $13.2 \pm 0.7^{*}$ & $15.0 \pm 1.5^{*}$ & $12.4 \pm 1.0$ & $15.6 \pm 0.5^{*}$ & $16.7 \pm 1.7^{*}$ & $17.2 \pm 1.0^{*}$ \\
\hline 18:0 & $1.5 \pm 0.2$ & $6.0 \pm 0.6$ & $6.2 \pm 0.7$ & $3.4 \pm 1.5$ & $5.7 \pm 0.6$ & $5.7 \pm 0.5$ & $5.6 \pm 0.7$ \\
\hline $18: 1$ & $53.6 \pm 4.2$ & $11.3 \pm 0.6^{*}$ & $11.3 \pm 1.5^{*}$ & $8.4 \pm 2.2^{*}$ & $11.4 \pm 0.7^{*}$ & $11.9 \pm 0.7^{*}$ & $10.9 \pm 0.7^{*}$ \\
\hline $18: 2$ & $0.7 \pm 0.3$ & $29.1 \pm 0.8^{*}$ & $1.5 \pm 0.3$ & $3.9 \pm 2.6$ & $1.3 \pm 0.1$ & $2.0 \pm 0.3^{*}$ & $1.7 \pm 0.1^{*}$ \\
\hline $18: 3$ & $0.3 \pm 0.2$ & $1.3 \pm 0.3^{*}$ & $13.5 \pm 2.4^{*}$ & $0.7 \pm 0.3$ & $0.4 \pm 0.1$ & $0.3 \pm 0.2$ & 0.00 \\
\hline $20: 3$ & $1.0 \pm 0.2$ & $6.8 \pm 0.6^{*}$ & $17.2 \pm 5.5^{*}$ & $34.7 \pm 1.2^{*}$ & $1.2 \pm 0.1$ & $1.0 \pm 0.2$ & $1.3 \pm 0.3$ \\
\hline $20: 4$ & $4.1 \pm 0.2$ & $7.7 \pm 0.3^{*}$ & $9.5 \pm 1.4^{*}$ & $1.4 \pm 0.1^{*}$ & $29.9 \pm 1.7^{*}$ & $3.6 \pm 0.1^{*}$ & $4.9 \pm 0.3$ \\
\hline $20: 5$ & 0.00 & $0.4 \pm 0.2$ & $1.0 \pm 0.9$ & $3.6 \pm 0.7^{*}$ & $0.1 \pm 0.1$ & $21.4 \pm 2.0^{*}$ & $2.0 \pm 0.02 *$ \\
\hline $22: 4$ & $2.1 \pm 0.7$ & $3.8 \pm 0.3$ & $3.1 \pm 0.6$ & $0.2 \pm 0.2^{*}$ & $15.5 \pm 0.3^{*}$ & $0.6 \pm 0.2$ & $1.4 \pm 0.8$ \\
\hline $22: 5$ & $1.2 \pm 0.1$ & $1.5 \pm 0.1$ & $1.7 \pm 0.3$ & $3.3 \pm 0.2^{*}$ & $1.7 \pm 0.1^{*}$ & $19.2 \pm 2.0^{*}$ & $1.2 \pm 0.1$ \\
\hline $22: 6$ & $1.9 \pm 0.2$ & $2.3 \pm 0.1$ & $1.7 \pm 0.3$ & $3.3 \pm 0.7$ & $1.7 \pm 0.1$ & $2.1 \pm 0.2$ & $37.6 \pm 4.7^{*}$ \\
\hline Saturated & $15.8 \pm 0.8$ & $22.5 \pm 1.4^{*}$ & $25.3 \pm 2.7 *$ & $13.7 \pm 6.0$ & $25.1 \pm 1.0$ & $26.7 \pm 2.6^{*}$ & $26.8 \pm 1.4^{*}$ \\
\hline Monosaturated & $61.2 \pm 3.3$ & $16.9 \pm 0.7^{*}$ & $16.9 \pm 1.8^{*}$ & $14.4 \pm 1.4^{*}$ & $16.9 \pm 0.7^{*}$ & $18.4 \pm 1.3^{*}$ & $17.0 \pm 0.7^{*}$ \\
\hline Polyunsaturated & $12.1 \pm 0.9$ & $55.2 \pm 1.4^{*}$ & $49.4 \pm 4.2^{*}$ & $53.5 \pm 3.7^{*}$ & $52.8 \pm 1.6^{*}$ & $50.7 \pm 3.6^{*}$ & $50.2 \pm 3.5^{*}$ \\
\hline Double bond index & $1.27 \pm 0.06$ & $1.55 \pm 0.24$ & $2.03 \pm 0.11 *$ & $2.56 \pm 0.21^{*}$ & $2.45 \pm 0.06^{*}$ & $2.72 \pm 0.19 *$ & $3.01 \pm 0.13^{*}$ \\
\hline Chain-length index & $17.9 \pm 0.1$ & $18.2 \pm 0.1$ & $18.3 \pm 0.2$ & $19.0 \pm 0.2^{*}$ & $19.0 \pm 0.03^{*}$ & $18.9 \pm 0.2^{*}$ & $19.2 \pm 0.1^{*}$ \\
\hline
\end{tabular}

Cells were grown for 2 days with $20 \mu \mathrm{M}$ supplemental fatty acid. After medium was removed, cells were washed 3 times and extracted with $\mathrm{CHCl}_{3}-\mathrm{CH}_{3} \mathrm{OH}(2: 1, \mathrm{vol} / \mathrm{vol})$, and lipid extracts subjected to alkaline hydrolysis. Fatty acids contained in saponifiable fraction were methylated, and methyl esters were separated by GLC. Heptadecanoic acid methyl ester was added as the internal standard. Individual fatty acid peak areas were expressed as a percentage of total fatty acid peak area. Values do not total $100 \%$ because only those fatty acids that exhibit appreciable changes in composition are listed. Fatty acids are designated by no. of carbons:no. of double bonds that they contain; e.g., arachidonic acid, 20:4, contains 20 carbons and 4 double bonds. Values represent analyses performed on at least 3 separate samples \pm SE. Included in computations for amount of unsaturation, chain length, and average no. of double bonds are fatty acids listed above as well as peaks identified as 14:0, 16:1, 18:4, 20:1, 20:2, 22:1, and 24:0. Unidentified peaks comprised 4.2-18.4\% of total falty acids. Chain length denotes average no. of carbons per fatty acid contained in cell lipids; double bonds indicates average no. of double bonds per fatty acid. * Significantly different from oleic acid supplemented cells at $P<0.05$.

increases occurred with linoleic acid, arachidonic acid, eicosatrienoic acid and DHA, and the composition of the cell lipids in each case was considerably different from the cells supplemented with oleic acid. Although less linolenic and eicosapentaenoic acids were present in the cell lipids after supplementation with these acids, substantial increases in their elongation products were detected. When the amounts of the elongated and unmodified fatty acids were added, the total enrichments obtained with both of these fatty acids was similar to those obtained with linoleic acid, arachidonic acid, eicosatrienoic acid, and DHA.

The percentage compositional changes reported in Table 3 reflect substantial changes in the amount of these fatty acids present in the cell lipids. For example, cells supplemented with arachidonic acid contained $123 \pm$

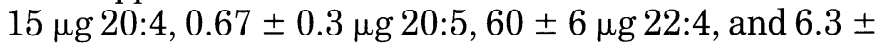
$0.1 \mu \mathrm{g} 22: 5$ per mg cell protein $(n=4)$. By contrast, those supplemented with eicosapentaenoic acid con-

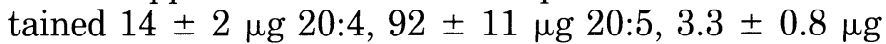
$22: 4$, and $79 \pm 15 \mu \mathrm{g} 22: 5(n=4)$. However, the total amounts of fatty acid present in the cell lipids were similar in both cases, $391 \pm 33$ compared with $399 \pm 30$ $\mu \mathrm{g} / \mathrm{mg}$ cell protein, respectively. Cells enriched with oleic acid, which do not produce a clearly discernible radical adduct, also contained a similar amount of total fatty acid, $431 \pm 13 \mu \mathrm{g} / \mathrm{mg}$ cell protein $(n=4)$.

When the various fatty acid-modified U937 cells were subjected to ferrous iron-mediated oxidant stress, radical adducts were detected by EPR spectroscopy (Fig. 5). The hyperfine splitting constants determined from the spectra produced by cells after supplementation with polyunsaturated fatty acids indicate that, as in the case of DHA supplementation, the radicals trapped by POBN are carbon-centered species. The adducts generated by the cells supplemented with eicosapentaenoic, arachidonic, and eicosatrienoic acids have hyperfine splitting values centered around $a^{\mathrm{N}}=15.66 \mathrm{G}$ and $a^{\mathrm{H}}=2.54 \mathrm{G}$ (Table 4). The low signal-to-background ratio precluded the extraction of accurate hyperfine splitting values from the spectra generated by cells supplemented with linolenic, linoleic, or oleic acids or the cells grown without fatty acid supplementation. However, the position and shape of these spectra resemble the spectra of the carbon-centered radical adducts generated by the DHA-enriched cells.

Spectra obtained with DHA-enriched cells contain enough information for successful computer simulation. A typical spectrum obtained from a suspension of DHAenriched cells exposed to $\mathrm{FeSO}_{4}$ in the presence of POBN is shown in Fig. 6A. The asymmetry in the spectrum suggests that more than one species is present. Indeed, the simulation, Fig. $6 B$, provided the best fit when the model contained two radical species. Both simulated spectra are carbon-centered radical adducts of POBN, the first with splitting constants of $a^{\mathrm{N}}=15.45 \mathrm{G}$ and $a^{\mathrm{H}}=2.89 \mathrm{G}$ (Fig. $6 C$ ) and the second with $a^{\mathrm{N}}=$ $15.94 \mathrm{G}$ and $a^{\mathrm{H}}=2.05 \mathrm{G}$ (Fig. 6D). A third radical species representing a POBN artifact (4) is shown in Fig. $6 E$ and is included in the composite simulated spectrum. Simulations also were performed on spectra obtained from cells enriched with eicosapentaenoic, arachidonic, and eicosatrienoic acids (Table 4). In all of these cases, the hyperfine coupling constants extracted from the experimental and the simulated spectra agree very well with those reported for POBN carbon-centered 


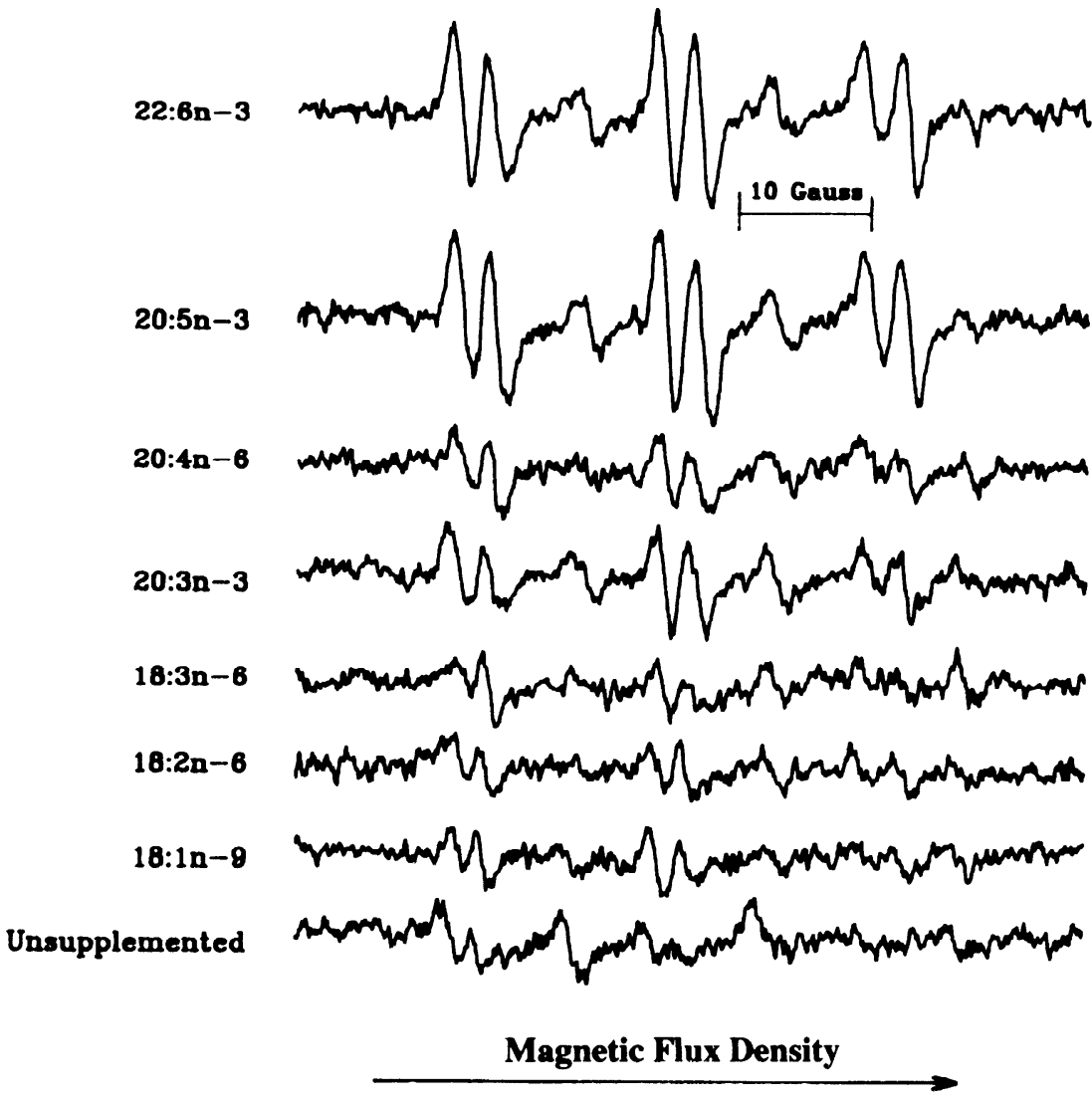

Fig. 5. Effect of supplementation with different fatty acids on POBN spin adduct signal intensity. U937 cells were grown for 2 days in medium containing 20 $\mu \mathrm{M}$ supplemental fatty acid and then washed 3 times with PBS. Fatty acid-enriched U937 cells $\left(2 \times 10^{6}\right)$ were incubated with $10 \mathrm{mM}$ POBN and $100 \mu \mathrm{M}$ $\mathrm{FeSO}_{4}$ in a total volume of $0.5 \mathrm{ml}$ air-saturated PBS. Supplemental fatty acid to which each of cultures was exposed is listed.

radical adducts generated during lipid peroxidation $(5$, $9,10,22$ ).

The amounts of radical adduct trapped by POBN from cells enriched with DHA or eicosapentaenoic acid, calculated using the 3-carboxy-proxyl standard, were greater than those obtained from cells enriched with the other fatty acids (Fig. 7). Comparisons with the fatty acids containing 20 carbons suggest that more radicals are trapped from cells enriched with the $n-3$ as opposed to $\mathrm{n}-6$ fatty acids. Particularly important in this regard is the fact that more radicals were trapped when the cells were enriched with $20: 3(n-3)$ than $20: 4(n-6)$, even though the n-3 fatty acid contains one less double bond. However, as shown in Table 3, the lipids from the cells enriched with $20: 3(n-3)$ contain slightly more average number of double bonds per fatty acyl chain than those from the cells enriched with 20:4(n-6), possibly accounting for the difference in spin adduct formation.

Location of trapped radical. A DHA-enriched cell suspension was treated with ferrous iron and the incubation medium was then rapidly separated from the cell pellet by centrifugation. The free radical spectrum detected in the intact system before centrifugation is shown in Fig. 8A. After the medium and cells were separated, however, the carbon-centered radical adduct was detected only in the supernatant solution and not in the cell pellet (Fig. 8, $B$ and $C$ ). In a similar experiment, a DHA-enriched cell suspension was centrifuged initially to separate the cells from the medium, and each fraction was then exposed separately to ferrous ironinduced oxidant stress. No free radical was observed with the cell-free medium (Fig. $8 D$ ); a radical adduct was

Table 4. POBN spin adduct hyperfine splitting constants

\begin{tabular}{|c|c|c|c|c|c|c|}
\hline \multirow{3}{*}{$\begin{array}{c}\text { Fatty Acid } \\
\text { Supplement }\end{array}$} & \multicolumn{6}{|c|}{ Hyperfine Splitting Constants, G } \\
\hline & \multicolumn{2}{|c|}{ Fxperimental } & \multicolumn{2}{|c|}{$\begin{array}{l}\text { Simulated } \\
\text { radical } 1\end{array}$} & \multicolumn{2}{|c|}{$\begin{array}{l}\text { Simulated } \\
\text { radical } 2\end{array}$} \\
\hline & $a^{\mathrm{N}}$ & $a^{\mathrm{H}}$ & $a^{\mathrm{N}}$ & $a^{\mathrm{H}}$ & $a^{\mathrm{N}}$ & $a^{\mathrm{H}}$ \\
\hline Docasahexaenoic $[22: 6(n-3)]$ & $15: 61$ & 2.64 & 15.85 & 2.61 & 15.13 & 2.78 \\
\hline Eicosapentaenoic $[20: 5(n-3)]$ & 15.56 & 2.65 & 15.76 & 2.59 & 14.84 & 2.25 \\
\hline Arachidonic $[20: 4(n-6)]$ & 15.52 & 2.59 & 15.79 & 2.35 & 14.98 & 2.13 \\
\hline Eicosatrienoic $[20: 3(n-3)]$ & 15.58 & 2.62 & 15.91 & 2.18 & 15.49 & 2.56 \\
\hline
\end{tabular}

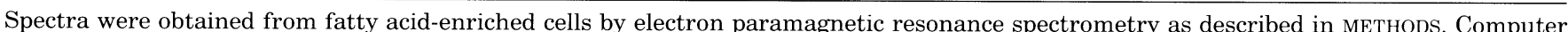

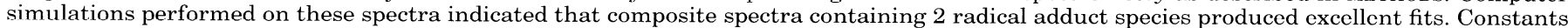

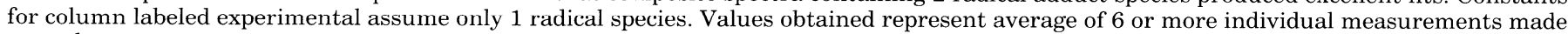
on each spectrum. 


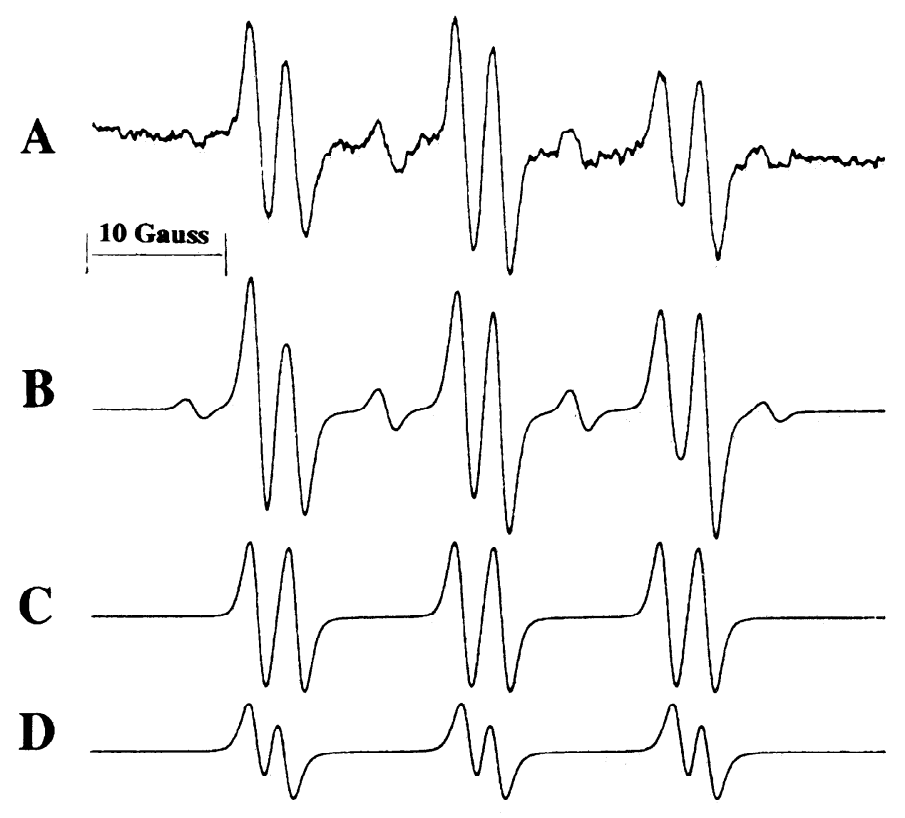

$\mathbf{E}$

\section{Magnetic Flux Density}

Fig. 6. Simulations of POBN spin adduct spectra. A: EPR spectrum of radical adducts detected at room temperature in solutions containing $2 \times 10^{6}$ U937 cells previously grown in a medium supplemented with $20 \mu \mathrm{M}$ DHA, $10 \mathrm{mM}$ POBN, and $100 \mu \mathrm{M} \mathrm{FeSO}_{4}$ in a total volume of 0.5 ml air-saturated PBS. EPR spectrometer conditions were those listed under METIIODS. $B$ : computer-generated composite spectrum of spectra $C, D$, and $E$, which are simulations based on data obtained from spectrum $A$. $C$ : simulated spectrum of carbon-centered POBN radical adduct: line width, $0.56 \mathrm{G}$; line shape, $53 \%$ Lorentzian-47\% Gaussian mole ratio, $0.58 ; a^{\mathrm{N}}=15.45 \mathrm{G}, a^{\mathrm{H}}=2.89 \mathrm{G}$. $D$ : simulated spectrum of carbon-centered POBN radical adduct: line width, $0.62 \mathrm{G}$; line shape, $70 \%$ Lorentzian-30\% Gaussian; mole ratio, $0.36 ; a^{\mathrm{N}}=15.94 \mathrm{G}, a^{\mathrm{H}}=$ 2.05 G. E: simulated spectrum of POBN artifact: line width, $0.56 \mathrm{G}$; line shape, $25 \%$ Lorentzian-75\% Gaussian; mole ratio, $0.06 ; a^{\mathrm{N}}=$ $14.54 \mathrm{G}, a^{\mathrm{H}}=14.44 \mathrm{G}$. This artifact arises from breakdown of POBN that can result in spin adduct species 2-methyl-2-nitrosopropane/ $\mathrm{H}$. detected only when the separated resuspended cell pellet was exposed to the ferrous ions (Fig. $8 E$ ). Taken together, these data indicate that although radical formation is cell-mediated, the resulting POBN spin adduct is localized to the extracellular fluid.

A possible reason why spin adducts were not detected in the cell pellet is that the intracellular contents might quench the radical adduct signal or catabolize the radical adducts after they are formed. To evaluate this possibility, DHA-enriched cells were homogenized, and the homogenate was exposed to $\mathrm{FeSO}_{4}$ in the presence of POBN. A spin adduct spectrum indicating the formation of a lipid-derived radical adduct was observed in the homogenate (data not shown). The spectral characteristics of this adduct are consistent with a carbon-centered lipid radical having hyperfine splitting constants of $a^{\mathrm{N}}=$ $15.59 \mathrm{G}$ and $a^{\mathrm{H}}=2.57 \mathrm{G}$, values similar to those calculated for the spectra produced by intact cells enriched with DHA. Based on protein content, the amount of radical adduct generated from the homogenate was similar to that generated by intact cells. Therefore the failure to detect cell-associated spin adducts is not due to quenching or destruction by the intracellular contents.

Effect of ascorbate. Ascorbate, which can serve as a pro-oxidant, was introduced into the system to increase the flux of free radicals produced by the $\mathrm{FeSO}_{4}$-mediated oxidative stress (15). When only $20 \mu \mathrm{M} \mathrm{FeSO}{ }_{4}$ was added to a mixture containing $2 \times 10^{6}$ cells enriched with DHA, $25 \mathrm{mM}$ POBN, and $100 \mu \mathrm{M}$ ascorbate, an EPR spectrum was obtained exhibiting a composite of the lipid-derived radical adducts and the ascorbate radical (Fig. 9A). In the absence of ascorbate, this concentration of $\mathrm{FeSO}_{4}$ is too low to produce an appreciable amount of lipid radicals under the conditions and instrument settings used (26). With ascorbate, the EPR signal intensity was increased substantially over that of spectra obtained with $100 \mu \mathrm{M} \mathrm{FeSO}_{4}$ alone (Fig. 9B). However, as seen in Fig. $9 A$, the ascorbate radical
Fig. 7. Effect of fatty acid supplementation on amount of spin adduct produced. Fatty acid supplementation was done as described in Figure 5. Incubations at room temperature contained $2 \times 10^{6}$ fatty acid-enriched U937 cells, $10 \mathrm{mM}$ POBN, and $100 \mu \mathrm{M} \mathrm{FeSO}_{4}$ in a total volume of $0.5 \mathrm{ml}$ PBS. Spin adduct amounts were determined by comparison with standard peak areas. Each bar represents results obtained from at least 3 separate experiments $\pm \mathrm{SE}$.

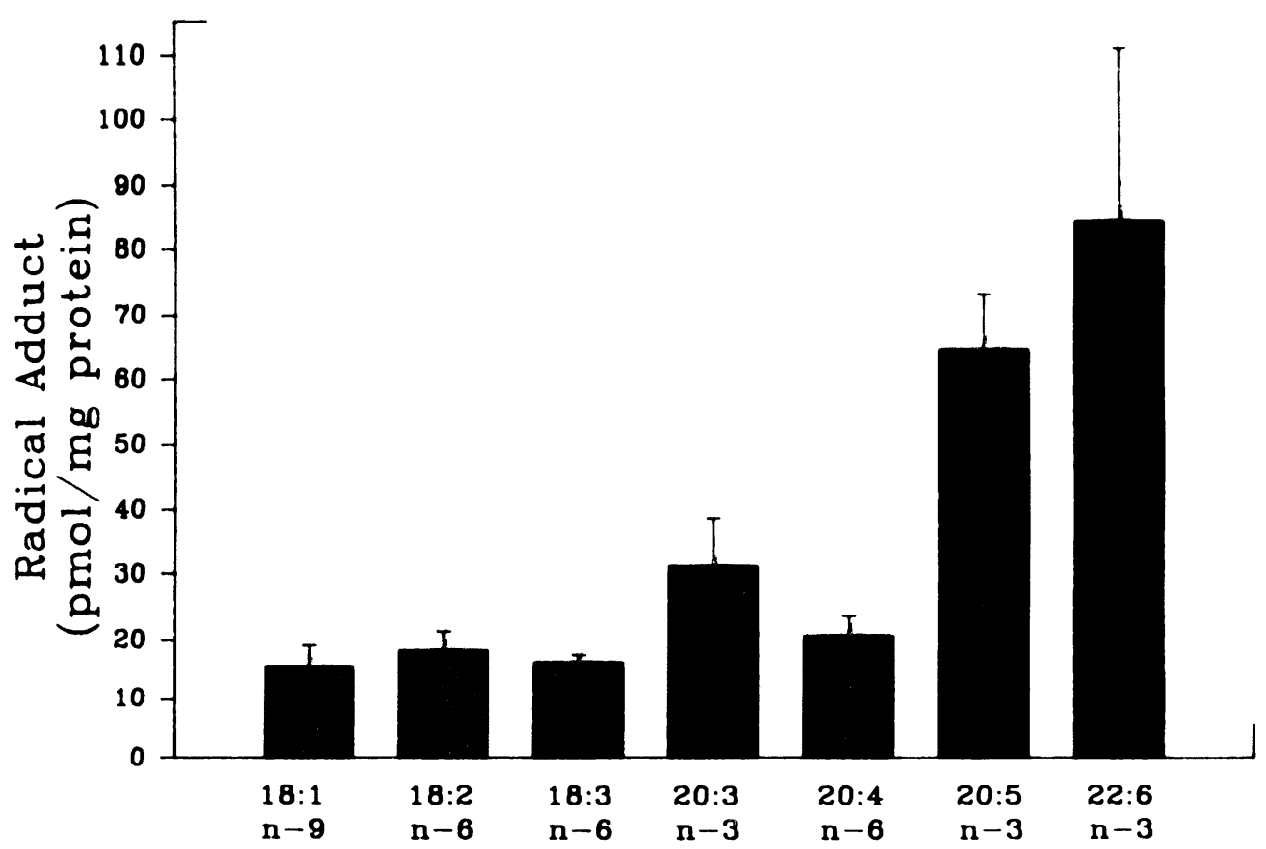




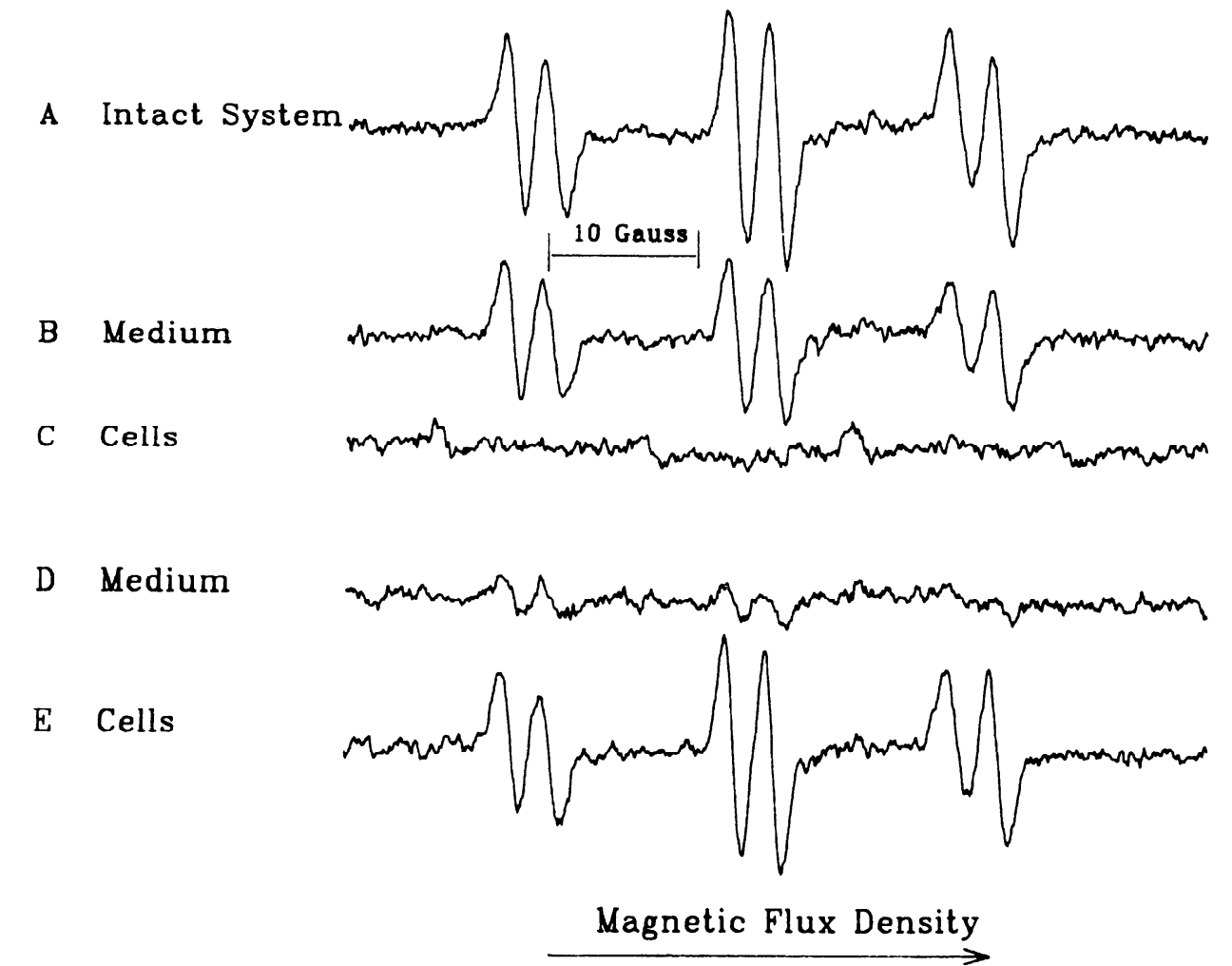

Fig. 8. Localization of POBN spin adducts in incubation mixture. Incubations were done at room temperature in $0.5 \mathrm{ml}$ air-saturated PBS solutions containing $10 \mathrm{mM}$ POBN and $2 \times 10^{6} \mathrm{U} 937$ cells that had been grown previously in medium supplemented with $20 \mu \mathrm{M}$ DHA. A: intact cells and medium together after incubation with $100 \mu \mathrm{M}$ $\mathrm{FeSO}_{4}$. B: supernatant fraction of incubation described in $A$, after 5 -min centrifugation at $15,000 \mathrm{~g}$. C: pellet fraction of incubation described in $A$, after centrifugation. $D$ : supernatant fraction, with $100 \mu \mathrm{M} \mathrm{FeSO}$ added after medium was separated from cells. $E$ : pellet fraction, with $100 \mu \mathrm{M} \mathrm{FeSO}$ added to cells after they were separated from initial medium and resuspended.

doublet spectrum $\left(a^{\mathrm{H}}=1.8 \mathrm{G}\right)$ is superimposed on the midfield doublet peaks of the lipid-derived radical spectrum.

\section{DISCUSSION}

Lipid peroxidation is a complex free radical chain reaction initiated by the abstraction of a bis-allylic hydrogen atom from a polyunsaturated fatty acid (6). Initiation of this process requires the presence of iron or other catalytic metals $(25,34)$. The initiation mechanism itself is a complex process that probably involves hydrogen atom abstraction by either $\mathrm{Fe}^{2+}$-generated hydroxyl radicals $(\mathrm{HO} \cdot)$, ferryl ions $\left(\mathrm{FeO}^{2+}\right)$, perferryl molecules $\left(\mathrm{Fe}^{2+}-\mathrm{O}_{2}\right)$, or possibly an $\mathrm{Fe}^{2+}-\mathrm{O}_{2}-\mathrm{Fe}^{3 \mid}$ com-

\section{A $100 \mu \mathrm{M}$ Ascorbate $+20 \mu \mathrm{N} \mathrm{FeSO}_{4}$}

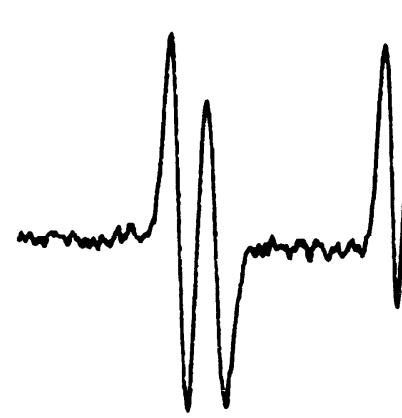

B $100 \mathrm{\mu M} \mathrm{FeSO} 4$
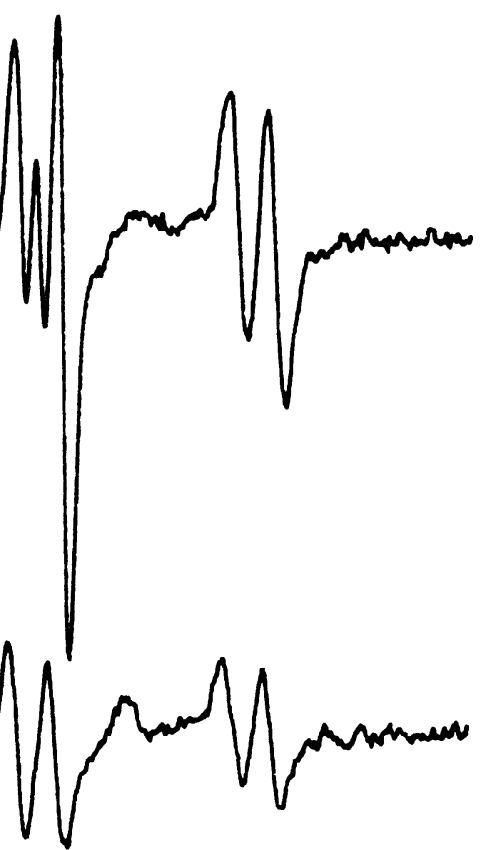

Fig. 9. Effect of presence of ascorbate on spectral intensity. U937 cells $(2 \times$ $10^{6}$ ) previously grown in medium supplemented with $20 \mu \mathrm{M}$ DHA were placed in $0.5 \mathrm{ml}$ air-saturated PBS containing 25 mM POBN. A: spectrum obtained after addition of $100 \mu \mathrm{M}$ ascorbate and $20 \mu \mathrm{M}$ $\mathrm{FeSO}_{4}$. B: spectrum obtained in presence of $100 \mu \mathrm{M} \mathrm{FeSO}{ }_{4}$ without added ascorbate. 
plex (34). Because the formation of the oxidizing species in each case requires ferrous iron, we employed $\mathrm{FeSO}_{4}$ as the initiating agent to simplify interpretations with this intact cell system. Using this experimental approach and POBN as the spin trap, we were able to detect lipid-derived free radicals generated in response to oxidant stress if the monocytic leukemia cells were enriched with any of the commonly occurring polyunsaturated fatty acids. Spin adducts were not detected under identical conditions with the two other spin traps tested, PBN and MNP. It is possible that either the kinetics of radical adduct formation were unfavorable, or these compounds were not present in the correct intracellular location to trap the radicals that were produced.

The largest EPR signal intensity occurred when the cells were supplemented with eicosapentaenoic acid or DHA. In the case of DHA, POBN spin adducts were clearly visible when the supplemental fatty acid concentration to which the cells were exposed during growth was $5 \mu \mathrm{M}$. Under these conditions DHA comprised $11 \%$ of the U937 cell fatty acid content (Fig. 3). For comparison, the DHA content in the retina and brain usually exceeds $15 \%$ of the tissue fatty acids (2). Because radicals were clearly visible at DHA contents $<15 \%$, radical formation in the U937 cells almost certainly is not an artifact due to the intracellular accumulation of polyunsaturated fatty acid that is above physiological levels. Our interpretation is that relative increases in polyunsaturated fatty acid magnify the inherent process to a level high enough to be detected by the currently available EPR spin-trapping techniques. The increase in spin adduct formation was roughly parallel to the increase in cellular DHA content (cf. Figs. 2 and 3). This is consistent with the interpretation that the extent of radical formation in response to a given level of oxidant stress depends on the availability of polyunsaturated substrate in the cell lipids. Studies with $\left[1-{ }^{14} \mathrm{C}\right] \mathrm{DHA}$ indicate that the U937 cells channel the newly incorporated fatty acid into three lipids, phosphatidylcholine, phosphatidylethanolamine and triglycerides. It is not therefore possible to distinguish which intracellular lipid is involved in the augmented radical response.

The present work demonstrates that enrichment of the U937 cells with n-6 as well as n-3 polyunsaturated fatty acids leads to an increase in spin adduct formation in response to the oxidant stress. However, the amount of POBN radical adduct formed was dependent on the chain length and degree of unsaturation of the supplemental fatty acid. Although precise comparisons are not possible because of differences in the degree to which the cells elongated and desaturated each fatty acid, the available results suggest that $n-3$ polyunsaturated fatty acids may be somewhat more effective than $n-6$ polyunsaturates. Therefore the magnitude of free radical formation resulting from a given level of oxidant stress probably depends on the type and amount of polyunsaturated fatty acids contained in the cell lipids. Alternatively, it is possible that the radicals generated from n-3 fatty acids are trapped more efficiently by POBN, so that the apparent increase may be a kinetic result of the spin-trapping assay.

Increases in malondialdehyde production $(24,28)$, ethane generation $(8,27)$, and conjugated diene formation (29) also occur when tissues are enriched with polyunsaturated fatty acids. To begin to explore how radical production relates to these processes, we compared radical adduct signal intensity and ethane production in the same preparations of U937 cells enriched with DHA. Both of these responses increased when the cells were exposed to iron-induced oxidative stress. By contrast, enrichment with oleic acid, which does not produce a measurable increase in spin adduct formation, resulted in only a very low level of ethane production. These results suggest that ethane generation and radical adduct formation are measuring similar processes. The quantitative relationship between the two processes is difficult to assess, however, because radical formation was measured within $5 \mathrm{~min}$, whereas $2 \mathrm{~h}$ were required for ethane collection.

Computer simulations of the EPR spectra were undertaken in an attempt to begin characterizing the lipid radicals formed by the intact cells. These simulations provide information about the minimum number of radical species that constitute the spectrum, their relative amounts and the hyperfine coupling constants. The simulations indicate that more than one carboncentered radical was trapped when the U937 cells were enriched with either the n-3 or n-6 polyunsaturated fatty acids. On the basis of chemical studies reported by others, we propose that the radicals trapped by POBN are formed by $\beta$-scission of the alkoxyl radical, LO forming $\cdot \mathrm{CH}_{2} \mathrm{R}$ and $\mathrm{R}^{\prime} \mathrm{CHO}(1,9,20)$. These include ethyl, pentyl, and pentenyl free radicals. Based on this, we suggest that pentyl radicals generated from the methyl end of the fatty acid chain are trapped when n-6 fatty acids undergo peroxidation, whereas pentenyl radicals are formed from this segment of the chain if $n-3$ fatty acids are oxidized. The ethyl radicals probably are derived from either internal segments of both species or the methyl terminus of $n-3$ fatty acids.

When oxidant stress was initiated with $\mathrm{FeSO}_{4}$ alone, the signal-to-background ratio of the POBN spin adducts was very low. The radical adduct signals were enhanced substantially by adding ascorbate to increase the flux of radical generation. Ascorbate usually serves as a biological antioxidant (30), but it also can serve as a prooxidant (15). The ascorbate monoanion $\left(\mathrm{AscH}^{-}\right)$, the form of ascorbic acid present at neutral $\mathrm{pH}$, is easily oxidizable and thus can serve as a reducing agent $(6,7)$ needed to recycle catalytic metals such as $\mathrm{Fe}^{3+} ; \mathrm{AH}^{-}$is oxidized while reducing $\mathrm{Fe}^{3+}$ to $\mathrm{Fe}^{2+}$. The resulting $\mathrm{Fe}^{2+}$ can initiate another round of free radical oxidation reactions by generating one electron oxidants such as $\mathrm{HO}$, ferryl ions, perferryl species, or an $\mathrm{Fe}^{2 !}-\mathrm{O}_{2}-\mathrm{Fe}^{3}$ complex under these experimental conditions and thereby increase lipid radical formation.

The fact that spin adducts were trapped in the extracellular fluid suggests that the actions of these lipid-derived carbon-centered radicals may not be confined just to the cells exposed to the oxidant stress. In 
this regard, other free radicals also are released by cells, including superoxide (31) and nitric oxide (11), and they have effects in the surrounding medium or adjacent cells $(3,19,32)$. The homogenate experiments indicate that the failure to detect spin adducts in the intact cell pellet is not due to their destruction or quenching of the signal by the intracellular contents. The vital dye studies indicate that exposure to POBN and iron was not acutely cytotoxic, making it unlikely that the radicals or spin adducts were released into the medium due to cell damage. Also, the assay done on isolated medium after it had been incubated with the cells (Fig. $8 D$ ) demonstrates that the radicals are not generated in the medium from lipids or particles released from the fatty acid-enriched cells. If the radicals are trapped intracellularly and the spin adducts quickly extruded from the cells, the detection of the adducts in the medium would not mean that the radicals themselves could be released from the cells. An equally plausible explanation of the present results, however, is that some of the lipid radicals are either released into the extracellular fluid and trapped there or generated in membranes that are exposed to the extracellular fluid and trapped at the cell surface. Because of the very short life of carbon-centered radicals, the possibility that they are generated near the cell surface seems more likely. This is consistent with the finding that the microsome fraction, which contains plasma membranes when isolated by the procedure utilized (33), is highly enriched in polyunsaturated fatty acids if the cells were grown in the presence of supplemental DHA (Table 2). Also, some POBN would be expected to associate with the surface membrane, since it is an amphipathic substance. If so, it would be properly located to trap any radicals generated in the plasma membrane. Based on these considerations, the present observations suggest that at least some lipid radicals formed in response to oxidant stress may be generated in a location where they are able to exert effects on extracellular structures. Such a process might have functional relevance even if it represents only a small fraction of the total lipid radicals produced.

This work was supported by National Heart, Lung, and Blood Institute Research Grant HL-49264.

Address for reprint requests: A. A. Spector, Dept. of Biochemistry, 4-403 BSB, University of Iowa, Iowa City, IA 52242-1109.

Received 6 April 1993; accepted in final form 14 January 1994.

\section{REFERENCES}

1. Albro, P. W., K. T. Knecht, J. L. Schroeder, J. T. Corbett, D. Marbury, B. J. Collins, and J. Charles. Isolation and characterization of the initial radical adduct formed from linoleic acid and $\alpha$-(4-pyridyl-1-oxide)- $N$-tert-butylnitrone in the presence of soybean lipoxygenase. Chem. Biol. Interact. 82: 73-89, 1992.

2. Alsted, A.-L., and C.-E. Høy. Fatty acid profiles of brain phospholipid subclasses of rats fed n-3 polyunsaturated fatty acids of marine or vegetable origin. A two generation study. Biochim. Biophys. Acta 1125: 237-244, 1992.

3. Bredt, D. S., P. M. Hwang, and S. H. Snyder. Localization of nitric oxide synthase indicating a neural role for nitric oxide. Nature Lond. 347: 768-770, 1990.

4. Britigan, B. E., S. Pou, G. M. Rosen, D. M. Lilleg, and G. R. Buettner. Hydroxyl radical is not a product of the reaction of xanthine oxidase and xanthine. J. Biol. Chem. 265: 17533-17538, 1990.

5. Buettner, G. R. In the absence of catalytic metals ascorbate does not autoxidize at $\mathrm{pH} 7$ : ascorbate as a test for catalytic metals. $J$. Biochem. Biophys. Methods 16: 27-40, 1988.

6. Buettner, G. R. The pecking order of free radicals and antioxidants: lipid peroxidation, $\alpha$-tocopherol and ascorbatc. Arch. Biochem. Biophys. 300: 535-543, 1993.

7. Buettner, G. R., and K. P. Kiminyo. Optimal EPR detection of weak nitroxide spin adduct and ascorbyl free radical signals. $J$. Biochem. Biophys. Methods 24: 147-151, 1992.

8. Burns, C. P., and B. A. Wagner. Heightened susceptibility of fish oil polyunsaturate-enriched neoplastic cells to ethane generation during lipid peroxidation. J. Lipid Res. 32: 79-87, 1991.

9. Chamulitrat, W., and R. P. Mason. Alkyl free radicals from the $\beta$-scission of alkoxyl free radicals as detected by spin trapping in a lipoxygenase system. Arch. Biochem. Biophys. 282: 65-69, 1990.

10. Connor, H. D., V. Fischer, and R. P. Mason. A search for oxygen-centered free radicals in the lipoxygenase/linoleic acid system. Biochem. Biophys. Res. Commun. 141: 614-621, 1986.

11. Curran, R. D., T. R. Billar, D. J. Stuehr, K. Hofmann, and R. L. Simmons. Hepatocytes produce nitrogen oxides from $\mathrm{L}$-arginine in response to inflammatory products of Kupffer cells J. Exp. Med. 170: 1769-1774, 1989.

12. Duling, D. R., A. G. Motten, and R. P. Mason. Generation and evaluation of isotropic EPR spectrum simulations. J. Magn. Reson. 77: 504-511, 1988.

13. Eaton, S. S., and G. R. Eaton. Signal area measurements in EPR. Bull. Magn. Reson. 1: 130-138,1980.

14. Guffy, M. M., J. A. North, and C. P. Burns. Effect of fatty acid alteration on adriamycin sensitivity in cultured L1210 murine leukemia cells. Cancer Res. 44: 1863-1866, 1984.

15. Girotti, A. W., J. P. Thomas, and J. E. Jordan. Prooxidant and antioxidant effects of ascorbate on photosensitized peroxidation of lipids in erythrocyte membranes. Photochem. Photobiol. 41: 267-276, 1985.

16. Hadjiagapiou, C., and A. A. Spector. Docosahexaenoic acid metabolism and effect on prostacyclin production in endothelial cells. Arch. Biochem. Biophys. 253: 1-12, 1987.

17. Halliwell, B., and J. M. C. Gutteridge. Role of free radicals and catalytic metal ions in human disease: an overview. Methods Enzymol. 186: 1-85, 1990.

18. Harris, P., and P. Ralph. Human leukemic models of myelomonocytic development: a review of the HL-60 and U937 cell lines. J. Leukocyte Biol. 37: 407-422, 1985.

19. Ignarro, L. J. Endothelium-derived nitric oxide: actions and properties. FASEB J. 3: 31-36, 1989.

20. Iwahashi, H., P. W. Albro, S. R. McGown, K. B. Tomer, and R.P. Mason. Isolation and identification of $\alpha$-(4-pyridyl-1-oxide)$N$-tert-butylnitronc radical adducts formed by the decomposition of the hydroperoxides of linoleic acid, linolenic acid, and arachidonic acid by soybean lipoxygenase. Arch. Biochem. Biophys. 284: $172-180,1991$

21. Kaduce, T. L., A. B. Awad, L. J. Fontenelle, and A. A. Spector. Effect of fatty acid saturation on $\alpha$-aminoisobutyric acid transport in Ehrlich ascites cells. J. Biol. Chem. 252: 6624-6630, 1977.

22. Knecht, K. T., B. U. Bradford, R. P. Mason, and R. G. Thurman. In vivo formation of a free radical metabolite of ethanol. Mol. Pharmacol. 38: 26-30, 1990.

23. Lees, M. B., and S. Paxman. Modification of the Lowry procedure for the analysis of proteolipid protein. Anal. Biochem. 47: 184-192, 1971 .

24. Lokesh, B. R., S. N. Mathur, and A. A. Spector. Effect of fatty acid saturation on NADPII-dependent lipid peroxidation in rat liver microsomes. J. Lipid Res. 22: 905-915, 1981.

25. Miller, D. M., G. R. Buettner, and S. D. Aust. Transition metals as catalysts of "autooxidation" reactions. Free Radical Biol. Med. 8: 95-108, 1990

26. North, J. A., A. A. Spector, and G. R. Buettner. Detection of lipid radicals by electron paramagnetic resonance spin trapping using intact cells enriched with polyunsaturated fatty acid. $J$. Biol. Chem. 267: 5743-5746, 1992. 
27. Odeleye, O. E., R. R. Watson, C. D. Eskelson, and S. I. Mufti. Dietary polyunsaturated fatty acid promotes peroxidation and its possible role in the promotion of cancer. Adv. Exp. Med. Biol. 283: 789-791, 1990.

28. Porter, N. A. Chemistry of lipid peroxidation. Methods Enzymol. 105: 273-282, 1984.

29. Recknagel, R. O., and E. A. Glende. Spectrophotometric detection of lipid conjugated dienes. Methods Enzymol. 105: 331-337, 1984.

30. Rees, S., and T. F. Slater. Ascorbic acid and lipid peroxidation: the cross-over effect. Acta Biochim. Biophys. Hung. 22: 241-249, 1987.
31. Rosen, G. M., and B. A. Freeman. Detection of superoxide generated by endothelial cells. Proc. Natl. Acad. Sci. USA 81: 7269-7273, 1984.

32. Rosen, H., and S. J. Klebanoff. Bactericidal activity of a superoxide anion-generating system. A model for the polymorphonuclear leukocyte. J. Exp. Med. 149: 27-39, 1978.

33. Wang, L., T. L. Kaduce, and A. A. Spector. Localization of 12-hydroxyeicosatetraenoic acid in endothelial cells. J. Lipid Res. 31: 2265-2276, 1990.

34. Yin, D., H. Lingnert, B. Ekstrand, and U. T. Brunk. Fenton reagents may not initiate lipid peroxidation in an emulsified linoleic acid model system. Free Radical Biol. Med. 13: 543-556, 1992.

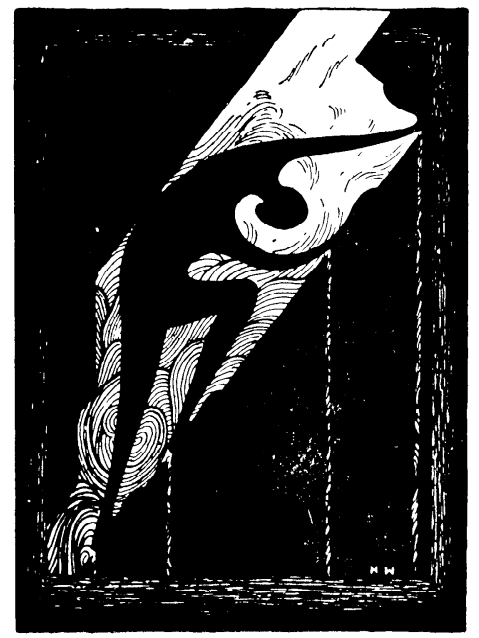

